\title{
Effects of Arbuscular Mycorrhiza in the Productivity of Maize and Fingermillet Relay Cropping System
}

\author{
Gautam Shrestha $^{1}$, Geeta Shrestha Vaidya ${ }^{2}$ and Binayak P. Rajbhandari ${ }^{1}$ \\ ${ }^{1}$ Himalayan College of Agricultural Sciences and Technology (HICAST) \\ ${ }^{2}$ Nepal Academy of Science and Technology, Khumaltar, Lalitpur \\ e-mail:gautam_utoo@yahoo.com
}

\begin{abstract}
Field experiments were conducted in farmer field in 2008 to scrutinize the effects of AM fungi in the productivity of maize/fingermillet cropping system in the rainfed dryland area of Kavrepalanchwok district. Following randomized complete block design, six treatments with four replications were maintained. Results showed significant effect of AM inoculation on plant height and yield of maize at $1 \%$ level of significance, whereas fingermillet was positive with nonsignificant difference on both parameters. Improvement in available soil phosphorus status was observed distinct in both maize (26.51 $\left.\pm 9.54 \mathrm{~kg} \mathrm{P}_{2} \mathrm{O}_{5} / \mathrm{ha}\right)$ and fingermillet $\left(30.11 \pm 15.15 \mathrm{~kg} \mathrm{P}_{2} \mathrm{O}_{5} / \mathrm{ha}\right)$ in arbuscular mycorrhiza treated plots (T3) than control (T1). Arbuscular mycorrhiza spore density was also improved in the mycorrhiza treatments with (T6) and without nitrogen and potash fertiliser (T3) as compared to control (T1) in both maize and fingermillet.
\end{abstract}

Key words: biofertiliser, endomycorrhiza, grain yield, soil productivity

\section{Introduction}

In sustainable and organic agricultural systems, the role of beneficial microorganisms in maintaining soil fertility and bio-control of plant pathogens may be more important than in conventional agriculture where their significance has been marginalized by high inputs of agrochemicals. Better understanding of the role of microorganisms with other management practices like fertiliser application is necessary for the development of sustainable management techniques of soil fertility and crop production.

Arbuscular mycorrhiza (AM) fungi are essential components of sustainable soil - plant systems (Schreiner et al. 2003) because of their role in increasing plant growth and nutrient uptake (Smith \& Read 1997). Effective arbuscular mycorrhizal associations have reduced the amount of phosphorus fertiliser needed to be applied to a plant or crop (Miyasaka et al. 2003). An association between mycorrhiza fungus and plant roots is beneficial to the plant when it is grown under low phosphorus or dryland (i.e. low rainfall, non-irrigated) conditions (Fageria 2009) and grow well under relatively harsh mineral stress conditions (Clark \& Zeto 2000) prevailed in subsistence agriculture in Nepal.

Phosphorus $(\mathrm{P})$ deficiency is a factor limiting crop production on tropical and sub-tropical soils (Fairhust et al. 1999, Mokwuny et al. 1986, Sanchez \& Salinas 1981). As nearly $49 \%$ soils of Nepal are acidic in reaction (Sherchan \& Karki 2006) most part of phosphorus is fixed in soil preferentially with iron and aluminum (Kanwar 1976) into unavailable forms. Alternative soil management techniques such as AM biofertiliser application is needed for resource poor farmers and has enormous potential for large scale agricultural systems and can be beneficial in sustainable production of main crops contributing to reduced input of expensive, environmentally harmful, low use efficient and limited phosphate fertilisers and chemical pesticides (Baar 2008, Shrestha 2007).

\section{Materials and methods}

Farmers' field experimentation was conducted at Mathurapati Phulbari VDC of Kavrepalanchwok 
district. This VDC is at a distance of $6 \mathrm{~km}$ from Dhulikhel, headquarter of Kavrepalanchwok district.

Detail of treatments:

\begin{tabular}{l|l}
\hline T1 & Control \\
\hline T2 & FYM only \\
T3 & AM inoculum \\
T4 & NK+FYM \\
T5 & FYM+NPK \\
T6 & FYM + NK + AM inoculum \\
\hline
\end{tabular}

- Each treatment had four replications. The above mentioned experiments were conducted in maize/ fingermillet - fallow cropping pattern.
- $\quad$ Experimental plot size: 25 sq. m. (each)

- Total experimental field size: 600 sq. m.

Mycorrhiza spores were isolated following wet sieving and decantation method adapted by Gerdemann $\&$ Nicolson (1963). Spores were mass produced in 1:1 sand and red soil mixture (autoclaved at $121^{\circ} \mathrm{C}$ and 15 lbs for $3 \mathrm{~h}$ ) with low phosphorus content (Table 1). Onion tubers were grown as host crop. Pots were watered regularly to maintain water levels to enhance proper growth of onion roots. Inoculum was harvested at 90 days of inoculation after achieving adequate number of spores and percentage root colonization. Root portions were chopped to make fine pieces of 1 to $2 \mathrm{~cm}$ length. Substrate along with spores and roots was mixed properly to make homogenized mixture of AM inoculum.

Table 1. Soil analysis results of inoculum media and farmers' field before planting maize (mean)

\begin{tabular}{l|l|l|l|l|l}
\hline Particular & Soil $\mathrm{pH}$ & $\mathrm{OM} \%$ & Total nitrogen $(\%)$ & $\mathrm{P}_{2} \mathrm{O}_{5}(\mathrm{~kg} / \mathrm{ha})$ & $\mathrm{K}_{2} \mathrm{O}(\mathrm{kg} / \mathrm{ha})$ \\
\hline Soil inoculum media & 5.94 & 2.20 & 0.15 & 2.80 & 39.62 \\
Before planting maize & 5.18 & 4.04 & 0.13 & 12.38 & 310.69 \\
\hline
\end{tabular}

AM inoculum application was done on the basis of 800 $\mathrm{g}$ in 1 sq. meter referring to Prabakaran et al. (1995). In fingermillet, it was mixed during nursery bed preparation, for $\mathrm{T} 3$ and $\mathrm{T} 6$ with additional application during planting time.
Varieties of crops used, sowing date, fertiliser doses, crop geometry and harvesting dates are as presented in the Table 2.

Table 2. Agronomical details of crops

\begin{tabular}{l|l|l|l|l|l}
\hline Crop & Variety & Sowing date & $\begin{array}{l}\text { Fertiliser dose } \\
\text { N:P:K kg/ha }\end{array}$ & $\begin{array}{l}\text { Crop geometry } \\
\text { R X P }(\mathrm{cm})\end{array}$ & Harvesting date \\
\hline $\begin{array}{l}\text { Maize } \\
\text { Finger millet }\end{array}$ & $\begin{array}{l}\text { Population 45 } \\
\text { Kavre Kodo }\end{array}$ & $\begin{array}{l}16^{\text {th }} \text { May } \\
9^{\text {th }} \text { July (nursery) }\end{array}$ & $\begin{array}{l}60: 40: 40 \\
80: 40: 30\end{array}$ & $\begin{array}{l}75 \times 25 \\
10 \times 5\end{array}$ & $\begin{array}{l}29^{\text {th }} \text { September } \\
23^{\text {rd }} \text { November }\end{array}$ \\
\hline
\end{tabular}

Biometric measurements were done in 5 fixed plants per replication. Total 120 plants were taken as sample for data collection. Soil analysis was done before planting maize and after harvest of each crop to determine the soil fertility status following standard procedures.

\section{Results}

\section{Plant height}

Plant heights in both maize and fingermillet were higher in T3 (AM inoculum) as compared to control (T1) (Table 3). It was higher in $T 3$ even than in $T 5$ in maize which was with the recommended dose of fertilisers and manures (Table 3 ) with significant difference.

Table 3. Plant height in $\mathrm{cm}\left(\mathrm{mean}_{ \pm} \mathrm{SE}\right)$

\begin{tabular}{l|l|l}
\hline Treatments & Maize & Fingermillet \\
\hline T1 & $186.25 \pm 7.39$ & $48.87 \pm 5.32$ \\
T2 & $228.25 \pm 3.92$ & $84.10 \pm 2.70$ \\
T3 & $241.75 \pm 12.00$ & $74.47 \pm 6.42$ \\
T4 & $236.50 \pm 6.98$ & $71.40 \pm 9.73$ \\
T5 & $233.75 \pm 4.39$ & $75.73 \pm 5.84$ \\
T6 & $239.25 \pm 9.29$ & $68.00 \pm 9.68$ \\
\hline
\end{tabular}




\section{Grain yield}

Grain yield is higher in AM inoculum (T3) treatment compare to control (T1) in both crops. Combined effect of farm yard manure, nitrogen and potash fertilisers and $\mathrm{AM}$ inoculum was found in grain yield of maize and fingermillet (Fig. 1).

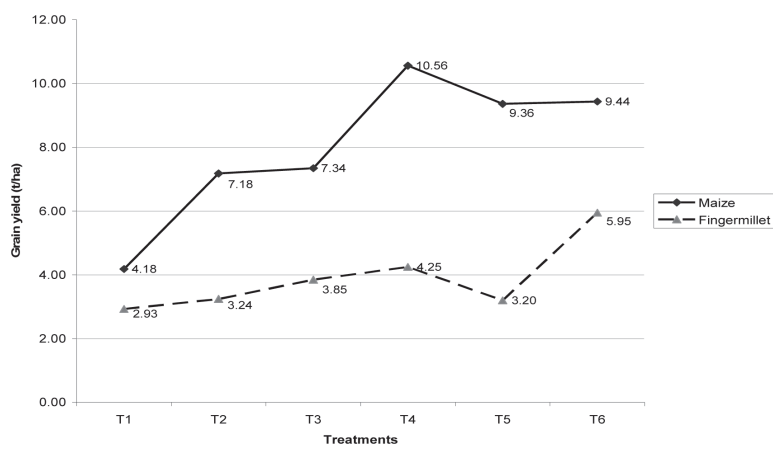

Fig. 1. Grain yield of maize and fingermillet

Maize grain yield was statistically significant at $1 \%$ level (Table 6) whereas fingermillet yield was non significant.

\section{Soil analysis}

Sandy loam type of soil was predominant in the area. First year soil fertility evaluation results showed that phosphorus content of the study area was low with slightly acidic soil $\mathrm{pH}$ (Table 1).

In maize, available phosphorus content in soil was higher in T3 and T6 where AM inoculum was applied without phosphorus fertiliser compare to $\mathrm{T} 5$ treatment with phosphorus fertiliser (Fig. 2).

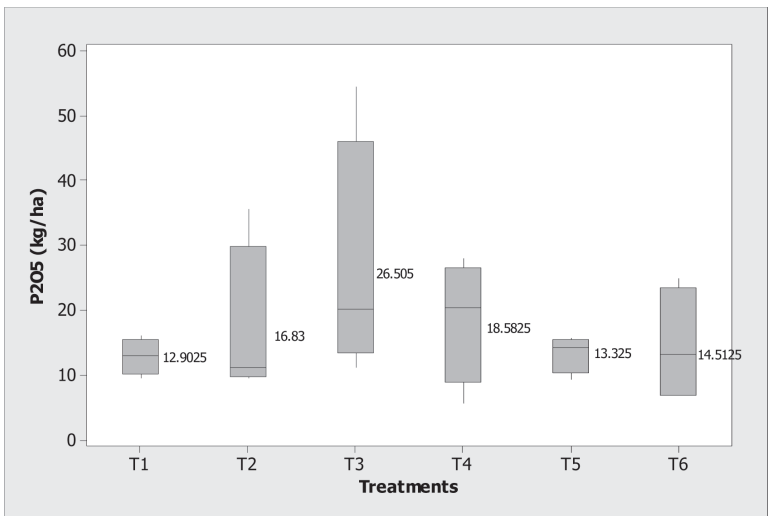

Fig. 2. Available phosphorus status after maize harvest
Phosphorus content was higher in the T3 and T6 treatments in fingermillet as compared to other treatments as a positive impact of AM inoculum application (Fig. 3).

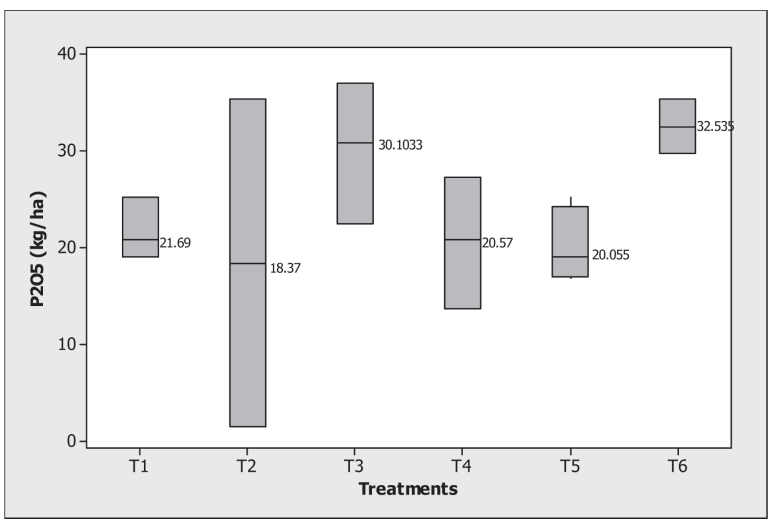

Fig. 3. Available phosphorus status after fingermillet harvest

\section{Mycorrhizal spore density}

Mycorrhizal spore density in fingermillet T3 (AM inoculum) treatment was higher than other treatments showing development of mycorrhizal population in dryland situation. In T6 treatment, spore density was higher in maize than that of other treatments. Spore density in $\mathrm{T} 1$ treatment in both crops was lowest

(Fig. 4).

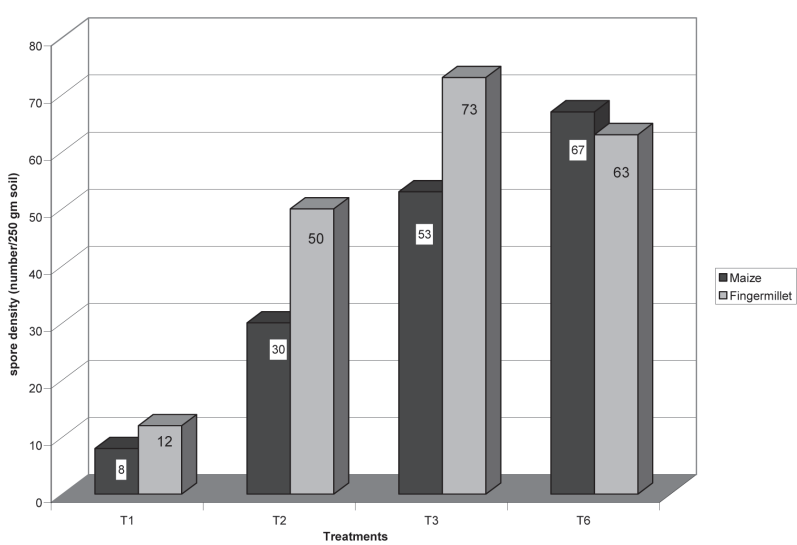

Fig. 4. Mycorrhiza population development in mycorrhiza inoculated soil 


\section{Discussion}

Confirming results of Stevens et al. (2002), our research revealed that total plant height difference was observed higher in phosphorus applied treatments (T5), both in maize $(233.75 \pm 4.39 \mathrm{~cm}$ in $\mathrm{T} 5$ than $239.25 \pm 9.29 \mathrm{~cm}$ in T6) and fingermillet $(75.73 \pm 5.84 \mathrm{~cm}$ in $\mathrm{T} 5$ than $68.00 \pm 9.68 \mathrm{~cm}$ in T6) than nitrogen and potash fertilisers and AM inoculum applied treatment (T6).]

In this study, soil analysis after maize showed $26.51 \pm 9.54 \mathrm{~kg} \mathrm{P}_{2} \mathrm{O}_{5} /$ ha in $\mathrm{T} 3$ after maize and $30.11 \pm 15.15$ $\mathrm{P}_{2} \mathrm{O}_{5} \mathrm{~kg} / \mathrm{ha}$ after fingermillet as compare to the control treatments (T1). These findings agree with those reported by Vogel-Mikuš and Regvar (2006) in line with Smith (2000) the contents of mineral nutrients e.g., phosphorus, significantly increased in inoculated plants, indicating functional exchange of nutrients and presumably carbohydrates between the partners due result of increased available phosphorus in soil.

Agreeing with Kahiluoto and Vestberg (1999) findings that low input cropping system including composting had higher spore density (32.2 and 44.2 per $100 \mathrm{ml}$ soil solution in spring and autumn respectively), this study also found higher spore density in FYM treatments (T2) (53 and 73 in maize and fingermillet respectively) compare to control (T1). SSD (2002) found that mycorrhiza spore count per $100 \mathrm{~g}$ soil was 22 and 15 , respectively in vesicular arbuscular mycorrhiza (VAM) + NPK and NPK only in pot trial. Conceding to SSD research results our study resulted that spores density was increased in the maize/millet relay system from 67 after maize and 63.0 spores per $250 \mathrm{~g}$ of soil after fingermillet in treatments with FYM, nitrogen and potash fertilisers and AM inoculum (T6). Acceding to Hameeda et al. (2007) in which they found about 15\% mycorrhizal colonization in control treatments, our research revealed mycorrhizal population development in control (T1) due to natural infection was observed in our research. Our findings is also supported by SSD (2003) also findings that VAM population in control plots in maize (2) and millet (1) compared to maize + $\operatorname{VAM}(12)$ and millet + VAM (5) in 100g soil sample taken.

In summary, mycorrhizal inoculation has proven to be the better alternative to the chemical fertilisers especially phosphorus to increase and maintain the productivity of crops in the past endeavors and so do in this research. Besides yield, mycorrhizal plants made their survival in drought conditions during dry months after planting. As lands of mid and high hills are slopy except in the valley plains, down flow of rainwater along with mycorrhiza has resulted into mere low growth of mycorrhizal spore density in the soil. Long term fertility trials with efficient strains of mycorrhizal inoculums will better perform in the field conditions.

\section{Acknowledgement}

Authors are grateful to the concerned farmers in Mathurapati Phulbari VDC for their cooperation and Sustainable Soil Management Programme (SSMP/ Helvetas Nepal) for providing financial support to this research.

\section{References}

Baar, J. 2008. From production to application of arbuscular mycorrhizal fungi in agricultural systems: requirements and needs. In: Mycorrhiza: genetics and molecular biology, eco-function, biotechnology, eco-physiology, structure and systematic. (Ed. A. Varma). (3 ${ }^{\text {rd }}$ edition). Springer - Verlag, Heidelberg: 361-374.

Clark, R.B. and S.K. Zeto. 2000. Mineral acquisition by arbuscular mycorrhizal plants. Journal of Plant Nutrition 23: 867 - 902.

Fageria, N.K. 2009. The use of nutrients in crop plants. CRC Press, Taylor and Francis Group. 448pp.

Fairhust, T., R. Lefroy, E. Mutert and N. Batjes. 1999. The importance, distribution and causes of phosphorus deficiency as a constraint to crop production in the tropics. Agro-forestry Forum 9: $2-8$.

Gerdemann J.W. and T.H. Nicolson, 1963. Spores of mycorrhizal endogone species extract from soil by wet sieving and decanting. In Transactions of the British Mycological Society 46: 235 - 244.

Hameeda, B., G. Harini, O.P. Rupela and G. Reddy 2007. Effect of composts or vermi-composts on sorghum growth and mycorrhizal colonization. African Journal of Biotechnology 6(1): 9-12.

Kahiluoto, H. and M. Vestberg 1999. Impact of cropping system on mycorrhiza. In: DARCOF Report. (Eds. J.E. Olesen, R. Eltun, M.J. Gooding, E.S. Jensen, and U. Köpke): p. $305-309$.

Kanwar, J.S. 1976. Soil fertility: theory and practice. Indian Council of Agricultural Research. New Delhi. 533pp.

Miyasaka, S.C., M. Habte, J.B. Friday and E.V. Johnson. 2003. Manual on arbuscular mycorrhizal fungus production and inoculation techniques. Soil and Crop Management 5: 4.

Mokwuny, A.S.H., S.H. Chien and E.R. Rhoes 1986. Reactions of phosphate with tropical African soils. 
In: Management of nitrogen and phosphorus fertilisers in Sub-Saharan Africa. (Eds. A. Mokwuny and P.L.G. Vlek). Martinus Nijhoff Publishers, Dordrecht, The Netherlands. pp. $253-282$.

Prabakaran, J., G. Arjunan, K.B. Ravi and N. Ramomoorthi. 1995. Performance of sorghum cultivars to vesicular-arbuscular mycorrhizae inoculation in Alfisol. In: Mycorrhizae: biofertilisers for the future: Proceedings of the third national conference on Mycorrhiza (Eds. A. Adholeya, and S. Singh). Tata Energy Research Institute, India. pp. $348-351$.

Sanchez, P. and J.G. Salinas 1981. Low input technology for managing Oxisols and Ultisols in tropical America. Advances in Agronomy 34:280 - 406.

Schreiner, R.P., S. Schneider, J.N. Pinkerton, and D. Bryla. 2003. Methyl bromide alternatives and mycorrhizal colonization in vineyard replant trails. In: Proceedings of the 2003 Annual Research Conference on Methyl Bromide Alternatives and Emissions Reductions (Ed. G.L. Obenauf). SAn Diego, CA. pp.116.

Sherchan, D.P. and K.B. Karki 2006. Plant nutrient management for improving crop productivity in Nepal. In: Improving plant nutrient management for better farmer livelihoods, food security and environmental sustainability. Proceedings of a regional workshop. Beijing, China, $12-16$
December 2005. FAO. Regional Office for Asia and the Pacific, Bangkok. pp. $41-57$.

Shrestha, G. 2007. Causes of soil fertility decline in maize based cropping patterns in Sindhupalchowk district. Bachelor degree thesis submitted to HICAST, Purbanchal University, Nepal. 70pp.

Smith, F. A. 2000. Measuring the influence of mycorrhizas. New Phytology. 148:4 - 6.

Smith, S.E. and D.J. Read. 1997. Mycorrhizal Symbiosis. ( $2^{\text {nd }}$ edition). Academic Press, London. 605pp.

SSD. 2002. Annual Report 2001/2002. Soil Science Division, Nepal Agricultural Research Council. Khumaltar, Lalitpur. pp. 52-54.

SSD. 2003. Annual Report 2002/2003. Soil Science Division, Nepal Agricultural Research Council. Khumaltar, Lalitpur. pp. 56-59.

Stevens, K.J., S.W. Spender and R.L. Peterson 2002. Phosphorus, arbuscular mycorrhizal fungi and performance of the wetland plant Lythrum salicaria L. under inundated conditions. Mycorrhiza 12: 277-283.

Vogel-Mikus K. and M. Regvar 2006. Arbuscular mycorrhiza as a tolerance strategy in metal contaminated soils - prospects in phytoremediation. In New topics in environmental research (Ed. D. Rhodes). Nova Science, Hauppauge, N.Y. pp. 37-56. 
Nepal Journal of Science and Technology 10 (2009) 